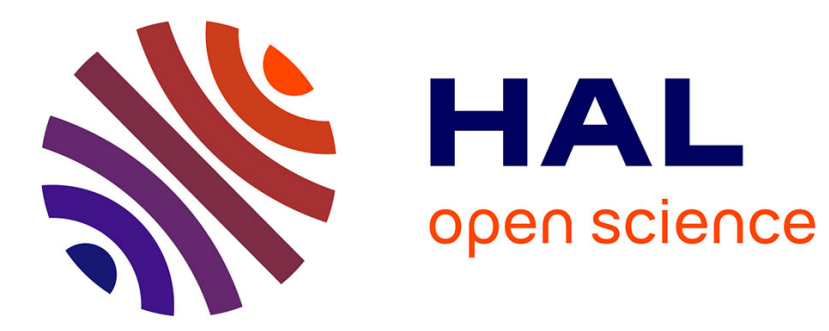

\title{
Practical considerations on the protein nutrition and feeding of tilapia
}

\author{
P. Luquet
}

\section{To cite this version:}

P. Luquet. Practical considerations on the protein nutrition and feeding of tilapia. Aquatic Living Resources, 1989, 2, pp.99-104. hal-02717814

\section{HAL Id: hal-02717814 \\ https://hal.inrae.fr/hal-02717814}

Submitted on 1 Jun 2020

HAL is a multi-disciplinary open access archive for the deposit and dissemination of scientific research documents, whether they are published or not. The documents may come from teaching and research institutions in France or abroad, or from public or private research centers.
L'archive ouverte pluridisciplinaire HAL, est destinée au dépôt et à la diffusion de documents scientifiques de niveau recherche, publiés ou non, émanant des établissements d'enseignement et de recherche français ou étrangers, des laboratoires publics ou privés. 


\title{
Practical considerations on the protein nutrition and feeding of tilapia
}

\author{
Pierre Luquet \\ INRA, Laboratoire d'Hydrobiologie, $B P n^{\circ}$ 7on, 97387 Kourou, Guyane française. \\ Reccived Scptember 2, 1988; accepted January 9, 1989.
}

Luquet P. Aquat. Liting Resour., 1989, 2, 99-104.

Abstract

Reliable data on tilapia nutrition and feeding are scarce. In the best documented ficld, that of protein requirement, current data show good agreement with available information on coldwater and warmwater fishes. Various feedstuffs have been used to satisfy the protein needs, but the effects of variations of their quality have not been sufficiently studied. The main problem lies in the assessment of the effects of natural food in open rearing structures; thus there are some discrepancies with the results obtained in laboratory. More insight on in situ nutrition of pond fish, as well as the management of the feedstuffs and feeding practices is needed.

Keynords : Tilapia, protein, amino acids, feedsturfs.

Considérations pratiques sur la nutrition et Talimentation protéiques chez le tilapia.

Résumé

Les donnces relatives à l'alimentation du tilapia sont rares et concernent essenticllement l'apport azoté. Les besoins quantitatifs en protéines apparaissent proches de 30 à $35 \%$ de la ration et sont homogènes avec ceux connus pour les autres espéces. Ces besoins peuvent partiellement être couverts par de multiples matières premiëres dont les potentialités n'ont toutefois pas toutes été explorées notamment quant à la variabilité de leur qualité. Dans des structures d'élevage ouvertes, la disponibilité de nourriture naturelle, par ses apports quantitatifs et qualitatifs, relativise les données acquises en laboratoire. Des recommandations sont effectuées pour la prise en compte de ces interférences, pour acquérir des bases complémentaires dans le domaine de la nutrition énergétique, ainsi que pour une meilleure gestion de la distribution de la nourriture.

Mots-clés : Tilapia, protëines, acides aminés, matières premières.

\section{INTRODUCTION}

Although the rearing of tilapia is of significant interest in selected arcas, there are very few data on its feeding and nutrition, or on the metabolism of different species despite the very wide range of natural fecding strategies. Jauncey and Ross (1982) have summarised most available knowledge in this field, and few new elements have come up since then. In practice, the diets which are used are elaborated, at best in the same way as for the diets of warmwater fishes (NRC, 1983), and at worst according to the availability of indigenous fecdstuffs.

Protein requirements and avaibility constitute the best documented field (Bowen, 1982; Tacon and Cowey, 1985), and numerous trials have been conducted to assess the nutritive value of feedstuffs capable of mecting the foresaid requirements. The present literature survey-which does not aim at being cxhaustive essentially presents a synthetis of current know- 
ledge in order to define the most urgent research needs.

\section{QUANTITATIVE PROTEIN REQUIREMIENTS}

Most studies on quantitative protein requirements have been conducted using young fish (from fry to a few grams), within small indoor fish tanks. In such conventional growth experiments, the most commonly used criteria are the weight gain and protein deposition, the optimum allowance being defined as the dietary level above which it is possible to note either a plateau or a decrease in weight gain.

Table 1 based on data either from original publications, or from other earlier compilations (Jauncey and Ross, 1982; Tacon and Cowey, 1985; Tabthipwon, 1985). In this table, protein requirements are expressed in different ways $i . e$. percent of diet, absolute daily needs, and quantity of protein required for $1 \mathrm{~kg}$ of weight gain.

When expressed as a percentage of the diet, the results are remarkably homogencous: in most cases the values range from 30 to 36 . There are only two erratic data (42 and 56) for O. mossambicus (Jauncey, 1982) and $O$. aureus (Winfree and Stickney, 1981). Thus, whatever the feeding behaviour in a given natural environment, protein requirements are very similar. This conclusion corroborates the concept of qualitative similarly of tilapia diets despite diversity of exploited food resources (Bowen, 1982).

Howcver, analysis of protcin requirement expressed as daily needs per kilogram of body weight shows some discrepancies as feeding rates vary within a very wide range ( 3 to $20 \%$ of BW per day). This leads to a daily requirement which varics considerably, since calculated values range from 9 to $68 \mathrm{~g}$ per $\mathrm{kg}$ per day. However, values higher than 25 are observed only with high feeding rates, and is not certain that all food was consumed. Consequently, the most probable values vary from 9 to 20 , i.e. two-fold. Still, Ogino $(1980 \mathrm{~b})$ pointed out how the feeding rate interacts with optimum rate of protein supply, and he clearly showed the inverse relationship in fishes. In this mind, Wang et al. (1985) calculated that, if for $O$. niloticus, the optimum dietary protein level required for maximal growth is $25 \%$ at a lecding rate of $3.5 \% \mathrm{BW}$, there is an inverse relationship between dietary levels and feeding rates for maximum $\mathrm{N}$ retention. The values ranged from $20 \%$ protein at a feeding level of $4.4 \% \mathrm{BW}$, to $40 \%$ at a $2.2 \% \mathrm{BWV}$ fecding rate. Data gathered in table 1 do not permit to obtain a same type of representation. Nevertheless, from the data of Balarin and Halen (1982) in Tabtipwon (1985) once can identify such a trend. To a certain extent, an increase in the feeding rate can make up for a low protein content in the diet.

While expressing requirements per unit weight gain (table 1), it is worth pointing out, from the data of Cruz and Laudencia (1977), that there is very poor protein efficiency in female slow growing fish. This is explained by the presence of broodstocks in the experimental aquaria, and as 0 . mossambicus are mouth-brooders they cannot eat efliciency while breeding. Thus, an effect of scx per se on nutrient needs cannot be inferred from these data, as all male populations do not show better food and protein efficiencies than mixed populations, at least when reproductive activities are not involved.

Jauncey and Ross (1982) recommend protein levels as high as $50 \%$ for alevins and lower levels ( 30 to 35 ) for $10-30 \mathrm{~g} O$. mossambicus. This is a trend generally accepted for other reared fish species. However, such a tendency in unclear when analysing data from table 1, and the few published studies carried out on large size tilapias show a $30 \%$ protein requirement (Hastings, 1973).

In brackish water ponds ( 29 part per thousand), Fineman-Kalio and Camacho (1987) found a better growth with $30 \%$ protcin diets than with lower protein levels. Higher protein diets were not tested in this experiment, but these results, which do not show any salinity effect, are in good agreement with the results of the very complete work of De Silva and Perera (1985) who tested a wide range of protein levels (10 to 48$)$ at 4 salinity levels $\left(0\right.$ to $\left.15 \times 10^{-3}\right)$ for young $O$. niloticus. The best combination was $28-30 \%$ protein at $10 \times 10^{-3}$ salinity. Further increases in dictary protein or salinity decreased the rate of growth, but when using higher protein levels fish grew best in freshwater.

Summing up the above data, it appears that tilapia species have a protein requirement of $30-35 \%$ of the diet, and that a $30 \%$ level constitutes a safe level. Some additional considerations should be taken into account with respect to the rearing environment. Under practical conditions, such as in ponds or even in cages, fish may have access to natural food which arc known to be protein rich. In this way, Lovell (1980) has calculated that if the protein requirement for 0 . aureus is close to $36 \%$, rates neighbouring $25 \%$ should be sufficient to obtain an optimal growth in ponds. Morcover, Wannigama et al. (1985) have not actually measured growth discrepancics in $O$. niloticus reared in $5 \mathrm{~m}^{3}$ cages and $5 \mathrm{ed} 3 \%$ of BW per day with diets containing 19 to $29 \%$ protein. Although a $30 \%$ protein diet seemed to produce the best growth in the experiment carried out by Newman et al. (1979) in manured tanks, no significant difference was observed between diets ranging from 20 to $35 \%$ protein. The authors concluded that it was more economical to use $20 \%$ protein diets than higher levels. This concept of optimum economic protein level should be kept in mind under mass production conditions.

\section{AMINO ACID REQUIREMENTS}

Most of the studies quoted above have been carried out using fishmeal or high quality feedstuff's as a 
Table 1. - Quantitative protein requirements of tilapia.

\begin{tabular}{|c|c|c|c|c|c|c|c|c|c|}
\hline \multirow[b]{2}{*}{ Species } & \multirow[b]{2}{*}{ Sire } & \multirow[b]{2}{*}{ Sex } & \multirow[b]{2}{*}{$\begin{array}{c}\text { Temperature } \\
\text { d 'C }^{-}\end{array}$} & \multirow[b]{2}{*}{$\begin{array}{c}\text { Salinity } \\
10^{-3}\end{array}$} & \multirow[b]{2}{*}{$\begin{array}{l}\text { Feeding } \\
\text { rate } \\
\% \text { body } \\
\text { weight }\end{array}$} & \multirow[b]{2}{*}{$\begin{array}{l}\text { Food } \\
\text { conversion } \\
\text { ratio }\end{array}$} & \multicolumn{3}{|c|}{ Protein Requirement } \\
\hline & & & & & & & $\begin{array}{l}\% \text { of } \\
\text { the dict }\end{array}$ & $\begin{array}{c}\text { g.kg } \\
\text { of body } \\
\text { weigh } \\
\text { day }^{-1}\end{array}$ & $\begin{array}{c}\mathrm{g}, \mathrm{kg} \text { of } \\
\text { weight } \\
\text { gain }\end{array}$ \\
\hline \multirow[t]{4}{*}{ O. niloticus } & alevin & - & $24-28$ & - & 15 & 1.78 & 35 & 52.5 & 623 \\
\hline & $0,3-0,8 \mathrm{~g}$ & - & - & - & 6 & 1.92 & 35 & 21.0 & 403 \\
\hline & $\begin{array}{c}3-4 \mathrm{~g} \\
20-28 \mathrm{mg}\end{array}$ & - & $\begin{array}{l}23-25 \\
23-25 \\
23-25 \\
23-25 \\
23-25\end{array}$ & $\begin{array}{l}- \\
0 \\
5 \\
10 \\
15\end{array}$ & $\begin{array}{c}\text { ad lib. (3.2) } \\
6 \\
6 \\
6 \\
6\end{array}$ & $\begin{array}{l}0.84 \\
2.27 \\
1.47 \\
1.45 \\
2.94\end{array}$ & $\begin{array}{l}31.4 \\
30.4 \\
30.4 \\
28.0 \\
28.0\end{array}$ & $\begin{array}{l}10.1 \\
18.2 \\
18.2 \\
16.8 \\
16.8\end{array}$ & $\begin{array}{l}264 \\
690 \\
447 \\
406 \\
493\end{array}$ \\
\hline & $2.8-100 \mathrm{~g}$ & & $15-32$ & 29 & $\begin{array}{c}5 \\
\text { (+ manure) }\end{array}$ & 1.68 & 30.7 & 15.3 & 516 \\
\hline O. hornorum $\times O$. niloticus (1) & $14.5 \mathrm{~g}$ & $\mathbf{M}$ & - & - & $\begin{array}{c}3 \\
(+ \text { manure })\end{array}$ & 1.8 & 30.5 & 9.2 & 549 \\
\hline O. niluticus $\times 0$. aureus (1) & $1.24 \mathrm{~g}$ & $\mathbf{M}$ & 26 & - & 3 & 1.17 & $\begin{array}{l}32 \text { (level } \\
\text { above no } \\
\text { tested) }\end{array}$ & 9.6 & 374 \\
\hline \multirow[t]{3}{*}{ O. mossambicus } & $34 \mathrm{~cm}$ & $\begin{array}{l}\mathrm{M} \\
\mathrm{F}\end{array}$ & $\tilde{z}$ & $\overline{-}$ & $\begin{array}{l}3 \\
3\end{array}$ & $\begin{array}{l}1.70 \\
3.29\end{array}$ & $\begin{array}{l}35.7 \\
35.7\end{array}$ & $\begin{array}{l}10.7 \\
10.7\end{array}$ & $\begin{array}{r}607 \\
1997\end{array}$ \\
\hline & $1.8 \mathrm{~g}$ & - & 27 & - & 5 & 1.46 & 42 & 25.5 & 613 \\
\hline & alevin & - & - & - & 3 & $1.6-1.8$ & $30-35$ & - & - \\
\hline \multirow[t]{2}{*}{0. aureus } & $0.37 \mathrm{~g}$ & $M$ & 27.6 & - & 8.8 & 1.46 & 36 & 31.8 & 525 \\
\hline & alevin & $M$ & $\begin{array}{l}24.5-32 \\
24.5-32\end{array}$ & $\overline{-}$ & $\begin{array}{l}\text { ad llab. } 20 \\
20\end{array}$ & - & 56 & - & - \\
\hline$T$, zillii & $\begin{array}{l}7.3 \mathrm{~g} \\
1.8 \mathrm{~g}\end{array}$ & - & $\begin{array}{l}24.5-32 \\
-\end{array}$ & $\overline{-}$ & $\begin{array}{r}20 \\
5\end{array}$ & $\begin{array}{l}2.05 \\
1.2\end{array}$ & 34 & 68 & 697 \\
\hline
\end{tabular}

(1): Hybrids.

protein source. Recommendations should therefore take into account the nutritive value of protein sources which are to be used: the digestive utilization as well as the biological value, which essentially depends on the essential amino acid content and balance.

Very few authors have conducted research on quantitative amino acid requirements. Only Jackson and Capper (1982) have estimated lysine (1.62\%), methionine $(0.53 \%)$, and arginine requirements $(1.52 \%)$ for $O$. mossambicus. Research in this ficld encounters methodological problems, e.g. the growth deficit which is usually recorded when diets based on cristalline amino acids are used. However, in the case of tilapia, the diet acidity does not secm to be the main depressive factor. Indeed, it is interesting to note that, in their study on chemical enhancement of fecding for Tilapia zillii, Adams et al. (1988) found a very strong aftractive effect of acidic group: the effectiveness of an enhancer increases as the $\mathrm{pH}$ decreases. Poor metabolic utilization related to the non-simultaneity of entrance into the cells for protcin synthesis would appear to be a possible explanation. Therefore, the utilization of diets with half of the amino acids provided in the free form has not enabled Jackson and Capper (1982) to obtain a growth equal to that obtained with a $40 \%$ protein diet. As the needs are a function of growth rate, this type of approach leads to too low recommendations (Cowcy and Luquet, 1983). Protein complementation techniques should be preferred to those of supplementation with cristalline amino acids.

In any case, extensive research on the determination of quantitative amino acid requirements does not seem to be a priority, as indirect approaches enable provide a rather accurate estimate of requirements. There is rather close agreement between the amino acid requirements for coldwater fish (rainbow trout) and those for warmwater fishes (catfish), when expressed in absolute terms and not as the percentage of the protein content. Thus, methionine, lysine, and arginine requirements are respectively of 20,44 and $30 \mathrm{mg} / 100 \mathrm{~g} / \mathrm{day}$ (Cowey and Luquet, 1983). As far as the relative proportions of different amino acids are concerned, analysis of published data shows good agreement between the requirements of salmon, catfish, eel, and carp on the one hand, and the amino acid composition of the Mesh on the other hand (Cowey and Luquet, 1983). In order to evaluate amino acid requirements for O. mossambicus, Jauncey et al. (1983) have used this type of approach, as well as that recommended by Ogino $(1980 a)$ which is based on daily amino acid deposition. Average values are summarised in table 2 . This type of approach offers a double interest: it is fast and reliable compared with a dose response type of method, and also provides a profile of requirements for all amino acids.

\section{PROTEIN SOURCES}

Almost all rescarch carricd out show that, for most species, fishmeal is the best protein source for tilapia. According to the above data, this is not surprising, at least as far as their amino acid balance is concerned. 
Table 2. - Quantitative amino acid requirements for 0 . mossambicus (from Jauncey et al., 1983).

\begin{tabular}{lcc}
\multicolumn{1}{r}{ Amino acids } & $\%$ of the diet & $\%$ of the protcin \\
\hline Arginine & 1.13 & 2.82 \\
Histidine & 0.42 & 1.05 \\
Isoleucine & 0.80 & 2.01 \\
Leucine & 1.35 & 3.40 \\
Lysine & 1.51 & 3.78 \\
Methionine & 0.40 & 0.99 \\
Phenyl alanine & 1.00 & 2.50 \\
Threonine & 1.17 & 2.93 \\
Tryptophane & 0.17 & 0.43 \\
Valine & 0.88 & 2.20 \\
\hline
\end{tabular}

Nevertheless, this should not be considered as a general recommendation since we have observed in Niger that some batches of fishmeal could only have negative effects, cren at low levels $(10-20 \%)$ in the diets. In theses cases, however, factors other than the fact that nitrogen is provided might be involved.

A traditional approach consists of totally or partly substituting for high protein content feedstuff (these are usually vegetable meal). The meals which are most commonly used are soybean meal, cotton sced meal, and groundnut meal followed by sunflower and rapeseed meal. In the case of tilapia, other plant sources have been tested, such as Leucaeca leucophala leaves (protein content: $24-25 \%$ ) Lemma sp. (protein content $24-25 \%$ ), Alocosia miccorhiza leaves (protein content $25-25 \%$ ) Lemma sp. leaves (protcin content: $38-31 \%$ ) and Azolla sp. (protein contant: $20-30 \%$ ), or even brewer's grains (protein content: $26 \%$ ).

The adequate use of these protein sources obviously depends upon their protein content, on their digestibility and on their amino acid balance, but also depends upon other factors which are much more difficult to assess, such as their content in antinutritive factors, since inbalances can be magnified under climatic or storage conditions which are common in the production and/or utilization areas.

Data on digestibility of such fecdstuffs, which are scarcely published, are quite heterogeneous because of the methods used for their evaluation. Furthermore, tilapia is not an "casy" fish, at least as regards the collection of facces by stripping (Barash et al., 1983). As an illustration, table 3 gathers some of the results we have obtained; these results are also an example of the negative side effects of some feedstuf's (shea butter seed meal, palmkernel meal and chicken manure) which entail a general depressive effect on digestible utilization on other components.

Laboratory tests, carricd out with checked-quality feedstuff other than fishmeal, generally indicate an ability to incorporate from 20 to $30 \%$, i.e. to provide proteins to cover for 25 to $50 \%$ of the protein requirements. The following data should be pointed out: a medium "bchaviour" of soy-bcan meal (Jackson et al, 1982; Viola and $A$ rieli, 1983a); good results with sunflower meal, which do not present any known
Table 3. - Digestibility $(\%)$ of proteins and of the organic matter for some available feedstuffs in Benin (Luquet, 1984, unpublished).

\begin{tabular}{lcc}
\hline & $\begin{array}{c}\text { Proteins } \\
\text { digestibility } \\
(\%)\end{array}$ & $\begin{array}{c}\text { Organic matter } \\
\text { digestibility } \\
(\%)\end{array}$ \\
\hline Fishmeal & 72 & 58 \\
Groundnut meal & 79 & 72.5 \\
Cotton seed meal & 31 & $0(-24)$ \\
Palm-kernel meal & $0(-26)$ & $0(-89)$ \\
Shea-butter seed meal & $0(-97)$ & 32 \\
Corn & 53 & 78 \\
Wheat bran & 20 & 34 \\
Brewers grains & 62 & 42 \\
Chicken manure & $0(-82)$ & $0(-130)$ \\
\hline
\end{tabular}

antinutritive factors in spits of a high cellulose content (Jackson et al., 1982); the medium results obtained with cotton seed meal (Jauncey and Ross, 1982; Jackson et al., 1982; Ojekwu and Ejike, 1984), gossypol not bcing considered as the negative factor (Robinson et al., 1984).

The utilization of whole plants such as Lemma (Gaigher et al., 1984; Tabthipwon, 1985) and Leucaena (Pantastico and Baldia, 1979; Jackson et al., 1982), gives contradictory results, but encouraging data are the positive results which where recorded by Ramos-Henao and Corredor, 1980, when they fed $T$. rendalli with Alocasia miccorhiza (tests in ponds).

As the type of rearing structure seems to have a considerable effect (Jackson et al., 1982), experimental conditions should be critically examined. Similarly, absolute values should also be cxamined as critically as comparative values.

When cognitive research is carried out in unfavourable experimental conditions some biased results may be obtained as a result of suboptimal growth. Conversely, during tests carried out in practical conditions, natural foods can interfere. Schroeder (1983) showed that natural food can represent from 50 to $70 \%$ of the total available food for tilapia, in pond culture, and even when a complete elaborated diet is provided. Conscquently, this "endogeneous" food may, to a certain extent, correct deficient diets (we often have to work with microphage fish); this gives results which are more positive in term of growth and conversion factor on than those obtained in laboratories.

\section{RECOMMENDATIONS}

From an economic point of view, given all the issues we have put forward and given all the major implicit deficiencies, we suggest that the following matters should be taken into consideration.

- Methods should be more precise so as to allow the evaluation of both quantitative and qualitative contributions of natural foods.

- A monitoring system is required to ensure good prescrvation of the feedstuffs (from oxidation and 
mycotoxins), and as all the more necessary since tilapia are reared in areas where climatic conditions favour such alterations.

- Apart from the formula, the distribution mode (feeding rate, timing) appears todays as having considerable influence on the metabolism. As in other fishes, it was observed by Carrillo et al. (1980) to affect the daily rhythms in pituitary cell activity and on liver metabolite levels for $O$. mossambicus.

From a more cognitive point of vicw, two points having obvious practical effects should be taken into consideration or should be extensively studied.

- The comparative utilization of different encrgetic substrates (amino acids, carbohydrates, lipids). The few studies conducted on carbohydrates utilization indicate that such substrates are a valuable energetic source for tilapia (Anderson et al., 1984) in contrast to the poor nutritive value recognized for coldwater fishes. Inversely, lipid seem to have a poor ability to have a sparing protein effect (Viola and Arieli, 1983 b).

- The functional activity of the digestive flora in terms of the modification of the substrates (proteins and carbohydrate), and the possible synthesis of vitamins such as B12 (Lovell and Limsuwan, 1982). In this field also, the interaction with the environment is of even more crucial interest.

\section{REFERENCES}

Adams M. A., P. 13. Johnsen, Z. Hong-qi, 1988. Chemical enhancement of feeding for the herbivorous fish Tilapia zilli. Aquaculture, 72, 95-107.

Anderson J., A. J. Jackson, A. J. Matty, B. S. Capper, 1984. Effects of dictary carbohydrate and fibre on the tilapia Oreochromis niloticus (L.). Aquaculture, 37, 303314.

Barash H., H. Ncumark, E. Helfer, B. Iosif, J. Itzkovich, 1983. An improved technology for determining diet digestibility by tilapia. In: International Symposium on tilapia in aquaculturc, L. Fishclson, Z. Yaron Eds., Tel Aviv University, $\mathrm{Tel}$ Aviv, Israel, 338-345.

Bowen S. H., 1982. Fecding, digestion and growth-qualitative considerations. In: The biology and culture of tilapias, R. S. V. Pullin, R. H. Lowc-McConnell Eds., ICLARM Conferences Proceedings 7, International Center for Living Aquatic Resources Management, Manilla, Phillipines, 141-156.

Carrillo M. A., S. Zanuy, J. Kuo, WV. Watanabe, 1980. Daily rhythms of liver CAMP, total liver lipids, prolactinlike hormone and growth hormone cell activitics in Sarotherodon mossambicus acclimated to different photoperiod regimes. Gen. Comp. Endocr., 41, 325-333.

Cowey C. B., P. Luquet, 1983. Physiological basis of protein requirements of fishes. In: Protein metabolism and nutrition, Vol. 1, M. Arnal, R. Pion, D. Bonin Eds., INRA, Paris, 365-384.
Cruz E. M., I. L. Laudencia, 1977. Protein requirements of Tilapia mossambica lingerlings. Kalikasan, Philipp. J. Biol., 6, 177-182.

Davis A. T., R. R. Stickney, 1978. Growth responses of Tilapia aurea to dietary protein quality and quantity. Trans. Am. Fish. Soc., 107, 479-483.

De Silva S. S., M. K. Perera, 1985. Ellects of dietary protein level on growth, food conversion, and protein use in young Tilapia nilotica at four salinities. Trans. Am. Fish. Soc., 584-589.

Fineman-Kalio A. S., A. S. Camacho, 1987. The effects of supplemental feeds containing different protein: energy ratios on the growth and survival of Oreochromis niloticus (L.) in brackish water ponds. Aquac. Fish. Manage., 18, 139-149.

Gaigher I. G., D. Porath, G. Granoth, 1984. Evaluation of duckweed (Lemna gibba) as feed for tilapia (Oreochromis niloticus $\times O$. aureus) in a recirculating unit. Aquaculture, 235-244.

Hastings IV. H., 1973. Projet regional de recherche et de formation piscicoles (Cameroun, République Centrafricaine, Gabon, Republique du Congo). Expériences relatives à la préparation d'aliments des poissons et à leur alimentation. FAO Doc. FI/RAF/66,054/1, 22 p.

Jackson A. J., B. S. Capper, 1982. Investigations into the requirements of the tilapia Sarotherodon mossambicus for dietary methionine, lysine and arginine in semi synthetic diets. Aquaculture, 20, 289-297.

Jackson A. J., B. S. Capper, A. J. Matty, 1982. Evaluation of some plant proteins in complete dicts for the tilapia Sarotherodon mossambicus. Aquaculture, 27, 97-109.

Jauncey K., 1982. The effects of varying dietary protein level on the growth, food conversion, protein utilization and body composition of juvenile tilapias (Sarotherodon mossambicus). Aquaculture, 27, 43-54.

Jauncey K., B. Ross, 1982. A guide to tilapia feeds and feeding. Institute of Aquaculture, University of Stirling, Scotland, $111 \mathrm{p}$.

Jauncey K., A. C. J. Tacon, A. J. Jackson, 1983. The quantitative essential amino acid requirements of Oreochromis (Sarotherodon) mossambicus. In: International symposium on tilapia in aquaculture, J. Fishclson, Z. Yaron Eds. Tel Aviv University, Tel Aviv, Israel, 328 337.

Lovell R. T., 1980. Feeding tilapia. Aquaculture magazine, 7, 42-43.

Lovcll R. T., T. Limsuwan, 1982. Intestinal synthesis and dictary nonessentiality of vitamin B12 for Tilapia nilotica. Trans. Am. Fish. Soc., 111, 485-490.

Mazid M. A., Y. Tanaka, T. Katayama, M. A. Rahman, K. L. Simpson, C. O. Chichester, 1979. Growth response of Tilapia zilli fingerlings fed isocaloric diets with variable protein levels. Aquaculture, 18, 739-742.

Newman M. IV., H. E. Huezo, D. G. Hugues, 1979. The response of all-male tilapia hybrids to lour levels of protein in isocaloric diets. Proc. World Maric. Soc., 10, 788-792.

NRC, 1983. Nutient requirements of warmwater fishes and shell-fishes. Revised Edition, National Academy Press, Washington D. C., 102 p. 
Ofojckwu P. C., C. Ejike, 1984. Growth response and feed utilization in the tropical cichlid Oreochromis niloticus niloticus (Linn.) fed on cottonseed-based artificial diets. Aquaculture, 42, 27-36.

Ogino C., $1980 \mathrm{a}$. Requirement of carp and rainbow trout for essential amino acids. Bull. Jap. Soc. Sct. Fish., 46, 171-174.

,$- 1980 b$. Protein requirements of carp and rainbow trout. Bull. Jap. Soc. Sci. Fish., 46, 385-388.

Pantastico J. B., J. P. Baldia, 1979. Supplemental feeding of Tilapia mossambica. Proc. World Symp. on Finfish Nutrition and Fishfeed Technology. Hamburg, 20-23 June, 1978, 1, 588-593.

Ramos-Henao A., G. G. Corredor, 1980. Effects of three management practices on the growth and production of Tilapia rendalli. Bamidgeh. 32, 41-45.

Robinson E. H., S. D. Rawles, P. W. Oldenburg, R. R. Stickney, 1984. Effects of feeding glandless or glanded cottonsced products and gossypol to Tilapia aurea. Aquaculture, 38, 145-154.

Schroeder G. L., 1983. The role of natural foods in Tilapia growth: a study based on stable isotope analysis. In: International Symposium on Tilapia in Aquaculture, L. Fishelson, Z. Yaron Eds., Tel Aviv University., Tel A viv, Israel, 312-322.

Shiau S., J. Chuang, C. Sun, 1987. Inclusion of soybean meal in tilapia (Oreochromis niloticus $\times O$, aureus) diets at two protein levels. Aquaculture, 65, 251-261.
Tabthipwon P., 1985. Utilisation de la lentille d'eau Lemna minor en Aquaculture. Application au Tilapia Sarotherodon niloticus. Thèse doctorat de spécialité, Institut National Polytechnique, Toulouse, $106 \mathrm{p}$.

Tacon A. G. J., C. B. Cowey, 1985. Protein and amino acid requirements. In: Fish energetics, P. Tytler, P. Calow Eds., Croom, London, Sydney, 155-183.

Viola S., Y. Arieli, 1983a. Nutrition studies with tilapia (Sarotherodon). 1. Replacement of fishmeal by soybeanmeal in feeds for intensive tilapia culture. Bamidgeh, 35, 9-17.

,$- 1983 b$. Nutrition studies with tilapia hybrids. 2. The effects of oil supplements to practical diets for intensive aquaculture. Bamidgeh, 35, 45-52.

Wang K., T. Takeuchi, T. Watanabe, 1985a. Effect of dietary protein levels on growth of Tilapia nilotica. Bull. Jap. Soc. Sci. Fish., 51, 133-140.

,$- 1985 b$. Optimum protein and digestible energy levels in diets for Tilapia nilotica. Bull. Jap. Soc. Sci. Fish., 51, 141-146.

Wannigama N. D., D. E. M. Weerakoon, G. Muthukumarana, 1985. Cage culture of $S$. niloticus in Sri Lanka: effect of stocking density and dietary crude protein levels on growth. In: Finfish nutrition in Asia. Methodological approaches to research and development, C. Y. Cho, C. B. Cowey, T. Watanabe Eds., Ottawa, Ont., IDRC, 113-117.

Winfree R. A., R. R. Stickney, 1981. Effects of dietary protein and energy on growth, feed conversion efficiency and body composition of Tilapia aurea. J. Nutr., 111, 1001-1012. 